\title{
KONJUGASI ANHIDRAT KIORAMFENIKOL-PROTEIN (CAP-BSA DAN CAP-KLH) UNTUK PRODUKSI IgG DARI SERUM KELINCI
}

\author{
Musyirna Rahmah Nst ${ }^{1)}$ Tri Budhi Murdiati ${ }^{2)}$ \\ 1) Sekolah Tinggi Ilmu Farmasi Riau (STIFAR) 2)BALITVET BOGOR.
}

\begin{abstract}
Abstrak
Dalam pengembangan metoda analisis residu antibiotik pada produk pangan hewani secara immunokimia telah dilakukan sintesis imunogen kloramfenikol (CAP) dengan protein Bovine Serum Albumin (BSA) dan Keyhole Limpet Hemocyanin (KLH) dengan metoda konjugasi mixed anhidrad. Hasil sintesis digunakan untuk produksi antibodi.Antigen dan antibodi yang dihasilkan dijadikan prangkat analisis residu antibiotik dengan Competitive Enzyme Linked Immunosorbent Assay (ELISA kompetitif). Hasil penelitian menunjukkan bahwa metoda konjugasi mixed anhidrad pada preparasi imunogen dengan jumlah CAP yang terkonjugasi ke grup amino bebas dari molekul protein BSA (CAP-BSA) adalah 18 unit dan ke protein KLH (CAP-KLH) adalah 782 unit. Antibodi poliklonal CAP-BSA dan CAP-KLH yang diproduksi dengan rata-rata kandungan IgG CAP-BSA 2,07 mg/ml dan IgG CAP-KLH 2,21 $\mathrm{mg} / \mathrm{ml}$.
\end{abstract}

Kata kunci : CAP, imunogen, antibodi, metoda konjugasi mixed anhidrad

\section{PENDAHULUAN}

Residu antibiotika dalam produk peternakan telah ditemukan dan dilaporkan baik di Indonesia maupun di negara lain (Bahri et al, 1990., FAO, 1990., Komar et al, 1990., Salysbury et al, 1990). Kloramfenikol dilarang pemakaiannya pada ternak di banyak negara karena efek toksik yang ditimbulkannya yaitu aplastik anemia ketika kandungan kloramfenikol meningkat melebihi $25 \mu \mathrm{g} / \mathrm{ml}$. Pemakaian antibiotika dalam bidang peternakan tidak dapat dihindarkan, karena antibiotika dalam bidang peternakan tidak hanya digunakan untuk pengobatan tetapi juga untuk pemacu pertumbuhan. Dalam usaha mencapai produksi semaksimal mungkin, antibiotika telah digunakan secara tidak tepat baik dalam memilih jenis antibiotika maupun dosis serta lama pemakaiannya (Sudarwanto, 1990., Murdiati dan Bahri, 1991). Tindakan tersebut telah memperluas peluang terdapatnya residu antibiotika dalam produk peternakan.
Walupun efek residu antibiotika tidak akan terlihat langsung akan tetapi konsumsi yang dilakukan secara terus menerus dalam dosis kecil akan membahayakan kesehatan manusia, seperti reaksi allergi, resistensi dan keracunan (Schlatter, 1990).

Analisis residu antibiotik dapat dilakukan secara kimia, mikrobiologi dan immunokimia. Analisis residu antibiotika dengan metoda immunokimia makin banyak mendapatkan perhatian. Umumnya ELISA (Enzyme Link Immunosorbent Assay) yang dikembangkan adalah ELISA kompetitif sedangkan teknik ELISA sandwich umumnya tidak digunakan untuk molekul kecil karena faktor halangan sterik (Haagsma and Water, 1992). Dixon dan Deborah pada 1992 telah melakukan pengembangan metoda ELISA untuk analisa antibiotik sulfonamida, $\beta$ laktam dan aminoglikosida. Kelebihan metoda ELISA adalah spesifik, sensitif, hemat, cepat dan mudah. 
Hal yang perlu diperhatikan dalam pengembangan metoda ELISA untuk deteksi residu antibiotika ataupun cemaran kimia lainnya adalah bahwa umumnya residu antibiotik merupakan senyawa dengan berat molekul kecil yang biasa disebut hapten. Hapten bersifat tidak imunogen artinya tidak dapat menstimulasi terbentuknya antibodi (Szurdoki et al., 1995). Oleh karena itu, antibiotika harus dibuat menjadi immunogenik secara konjugasi dengan enyawa yang mempunyai berat molekul yang besar umumnya protein.

Oleh karena itu dalam penelitian ini dilakukan sintesa immunogen yaitu kloramfenikol-protein konjugat yaitu BSA dan KLH dengan metoda konjugasi mixed anhidrat dan produksi antibodi poliklonal untuk deteksi kloramfenikol.

\section{METODOLOGI PENELITIAN}

Sintesis Imunogen CAP-BSA dan CAP KLH dengan Metoda Mixed anhhidrat

Immunogen (CAP-protein konjugat) disintesa dari kloramfenikol dan protein membentuk CAP-BSA dan CAP-KLH dengan metoda mixed anhidrad. Kloramfenikol suksinat (CAP suksinat) dilarutkan sebanyak 15 gr kedalam $1 \mathrm{ml}$ tetra hidro furan (THF) dan diaduk. Lalu ditambahkan $10 \mu \mathrm{l}$ tributilamin, $6 \mu \mathrm{l}$ Isobutilkloroformat secara perlahan-lahan pada suhu $4^{\circ} \mathrm{C}$ sambil terus diaduk secara cepat selama 20 menit (Larutan A). Larutan protein pdisiapkan dengan cara melarutkan $50 \mathrm{mg}$ protein bovine serum albumin (BSA) atau keyhole limpet hemocyanin (KLH) dalam 8,5 $\mathrm{ml}$ THF. Larutan protein ditambahkan secara tetes demi letes ke dalam larutan A sambil terus diaduk secara perlahan-lahan hingga larut selama 1 jam. Campuran ini dibiarkan selama 24 jam lalu dimurnikan dengan cara dialisa pada suhu $4^{\circ} \mathrm{C}$ selama 2-3 hari dengan menggunakan larutan PBS.

\section{Uji Kromatografi Cair Kinerja Tinggi (KCKT)}

Larutan imunogen dianalisa kandungan CAP yang tersisa dengan menggunakan metoda KCKT. Larutan standar dan larutan imunogen CAP dibuat dengan konsentrasi 10 ppm dalam metanol 40\%. KCKT disiapkan dengan mengatur kecepatan alir fase gerak (metanol $40 \%$ ) dan dikondisikan selama 1530 menit. Sebanyak $20 \mu \mathrm{l}$ CAP standar disuntikan kedalam injektor dengan

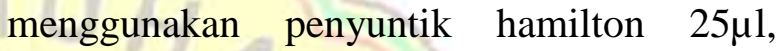
kemudian ditunggu hingga puncak CAP yang terdeteksi muncul seluruhnya pada detektor. Ulangi penyuntikan 2-3 kali untuk mendapatkan waktu retensi yang stabil. Lalu $20 \mu \mathrm{l}$ larutan imunogen disuntikan ke dalam injektor. CAP yang terdeteksi diamati dengan membandingkan waktu retensi puncak yang terdapat dalam larutan imunogen dengan standar.

\section{Penentuan Grup Amino Bebas dari CAP - Protein dengan Metode Habeeb}

Sebanyak $1 \mathrm{ml}$ larutan konjugat CAPProtein (CAP-BSA, CAP-KLH) dengan konsentrasi $0,6 \mathrm{mg} / \mathrm{ml}$ dalam bufer sodium asetat $10 \mathrm{mM}, \mathrm{pH} 4,5$ ditambahkan ke dalam $1 \mathrm{ml}$ sodium hidrogen karbonat $4 \%$ (W/V) $\mathrm{pH}$ 9, $1 \mathrm{ml}$ PSA $0,1 \%$ diaduk hingga homogen lalu diinkubasi selama 2 jam pada suhu $37^{\circ} \mathrm{C}$. Setelah itu ditambahkan 1ml SDS (hati-hati jangan sampai terbentuk endapan) dan $0,5 \mathrm{ml}$ $\mathrm{HCl} 1 \mathrm{M}$ dan diaduk hingga rata. Absorbansi dibaca pada panjang gelombang $340 \mathrm{~nm}$. Larutan blanko dan standar disiapkan dengan tahapan yang sama seperti diatas. Blanko hanya mengandung sodium asetat $10 \mathrm{mM}$ sedangkan standar protein adalah BSA dan KLH $(0,6 \mathrm{mg} / \mathrm{ml}$ dalam bufer sodium asetat $10 \mathrm{mM})$. 


\section{Produksi Antibodi}

Hewan percobaan yang digunakan untuk produksi antibodi adalah dua ekor kelinci New Zealand White yang diperoleh dari balai penelitian peternakan. Antibodi diproduksi dengan cara mengimunisasi kelinci dengan immunogen. Kelinci disuntik dengan larutan konjugat CAP-KLH $(0,67 \mathrm{mg} / \mathrm{ml})$ atau CAPBSA $(1 \mathrm{mg} / \mathrm{ml})$ sebanyakl $0,25-1 \mathrm{ml}$ secara subkutan. Pengambilan contoh darah untuk pengujian titer antibodi dilakukan 10 hari setelah boster pada intravena telinga sebanyak $\pm 50 \mathrm{ml}$. Darah disentrifus pada 3000 rpm selama 15 menit. Serum dikeluarkan dengan pipet pastur lalu disimpan pada suhu $-20^{\circ} \mathrm{C}$. Purifikasi antibodi dilakukan dengan metoda kromatografi kolom protein A sepharose dan konsentrasi antibodi ( $\mathrm{IgG}$ ) ditentukan dengan metoda spektrofotometri pada panjang gelombang $280 \mathrm{~nm}$.

\section{HASIL DAN PEMBAHASAN}

Keberhasilan sintesa immunogen dalam penelitian ini dapat diketahui dari jumlah grup amino bebas pada molekul kloramfenikol-protein. Hasil penentuan grup amino bebas dari konjugat CAP-BSA dan CAP-KLH dengan Metoda Habeeb diperoleh untuk CAP-BSA sebanyak 41 unit grup amino bebas dan untuk CAP-KLH sebanyak 1218 unit. Data ini menunjukkan bahwa sebanyak 18 unit molekul CAP yang terkonjugasi pada 1molekul BSA yang mempunyai grup amino bebas sebanyak 59 unit. Sedangkan jumlah CAP yang terkonjugasi pada 1 molekul KLH yang mempunyai 2000 grup amino bebas adalah sebanyak 782 unit. Pada Tabel 1 disajikan hasil analisa Metoda Habeeb dan pada Lampiran 2 dapat dilihat contoh perhitungan analisa data Metoda Habeeb.
Tabel 1. Hasil analisa Metoda Habeeb terhadap konjugasi CAP-BSA dan CAPKLH

\begin{tabular}{|c|c|c|c|c|}
\hline $\mathbf{N}$ & $\begin{array}{c}\text { Immunoge } \\
\mathbf{n}\end{array}$ & $\mathbf{B M}$ & $\begin{array}{c}\text { Jumlah } \\
\text { Group } \\
\text { Amino } \\
\text { Bebas }\end{array}$ & $\begin{array}{c}\text { Jumlah } \\
\text { hapten yang } \\
\text { terkonjugas } \\
\text { i ke protein }\end{array}$ \\
\hline 1 & BSA & 68.000 & 59 & \\
\hline 2 & CAP-BSA & & 41 & 18 \\
\hline 3 & KLH & $4,510 \operatorname{exp5}$ & 2000 & \\
\hline 4 & CAP-KLH & & 1218 & 782 \\
\hline
\end{tabular}

Sejumlah besar molekul hapten yang terkonjugasi pada molekul protein belum tentu akan bertindak sebagai immunogen yang baik dalam produksi antibodi. Antibodi dapat juga diproduksi dengan menggunakan immunogen yang hanya mengandung dua molekul hapten per mol protein. Menurut Chu (1990), jumlah hapten yang terikat pada protein yang diharapkan akan menghasilkan respon imun yang baik umumnya antara 1020 mol per mol protein.

Prinsip reaksi Metoda Habeeb merupakan reaksi Kalorimeteri yaitu reaksi antara molekul PSA dengan group amino bebas dari protein sehingga akan memberikan warna kuning dan diukur pada panjang gelombang $340 \mathrm{~nm}$. Semakin sedikit CAP yang terkonjugasi ke molekul protein (BSA dan KLH) maka group amino bebas dari protein yang bereaksi dengan PSA akan semakin banyak sehingga absorbansi semakin besar (lihat gambar 1a). Begitu juga sebaliknya pada gambar $2 \mathrm{~b}$ menunjukkan semakin banyak CAP terkonjugasi ke molekul protein maka group amino bebas dari protein yang bereaksi dengan PSA akan semakin sedikit sehingga absorbansi yang dihasilkan pun semakin kecil. 

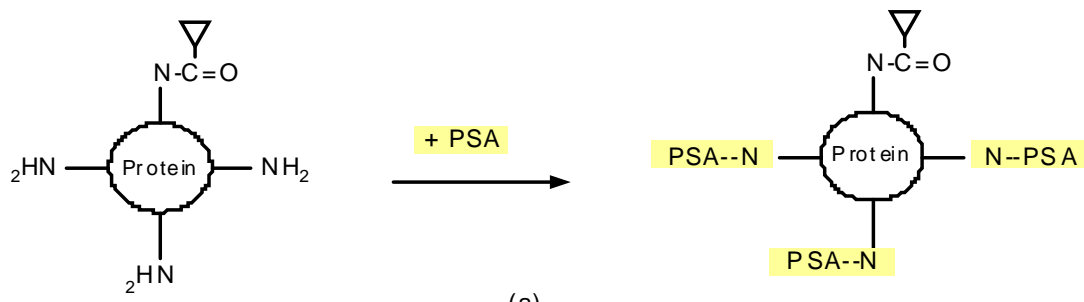

(a)<smiles>CC1(C(=O)NC2CC(N)CC(NC(=O)C3CC3)CC(NC(=O)C3(C)CC3)C2)CC1</smiles>

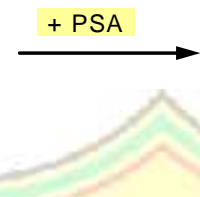

(b)

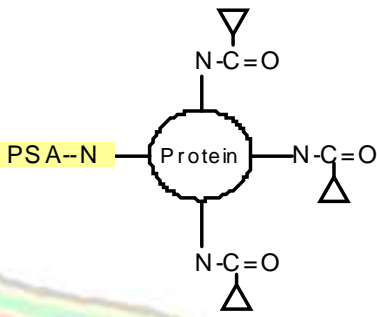

$\Delta$

Gambar 1. Prinsip Reaki Metoda Habeeb

Faktor yang penting dalam menentukan efektivitas reaksi konjugasi pada sintesa imunogen adalah posisi ikatan dan gugus aktif yang dimiliki molekul hapten yang terkonjugasi ke molekul protein. Molekul anhidrida dibentuk dari asam karboksilat (kloramfenikol natrium suksinat) dengan molekul klorida asam seperi isobutil kloroformat. Pada gambar 2 dan 3 dapat diketahui mekanisme sintesa CAP-suksinat dan mekanisme reaksi konjugasi kloramfenikol terhadap protein.

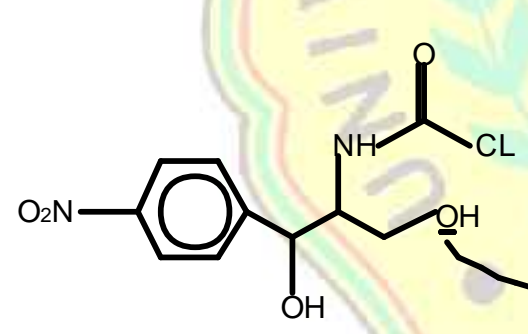

Kloramfenikol (C AP)

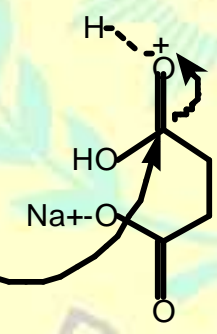

Na-Suksinat

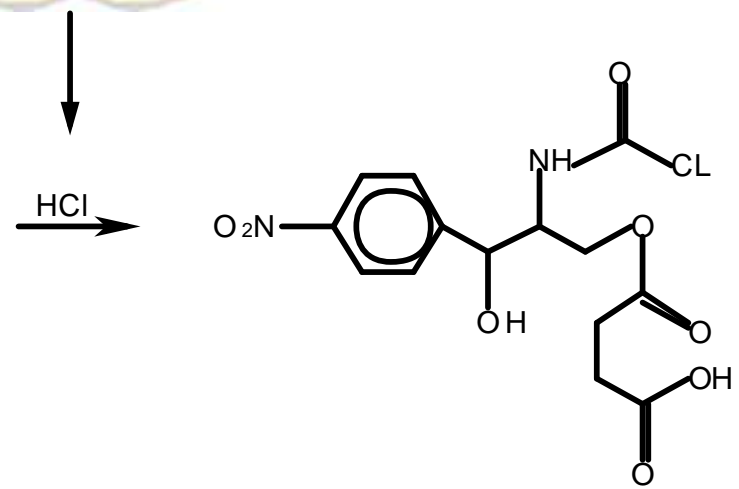

C AP-Suksinat

Gambar 2. Mekanisme Sintesa CAP-suksinat 


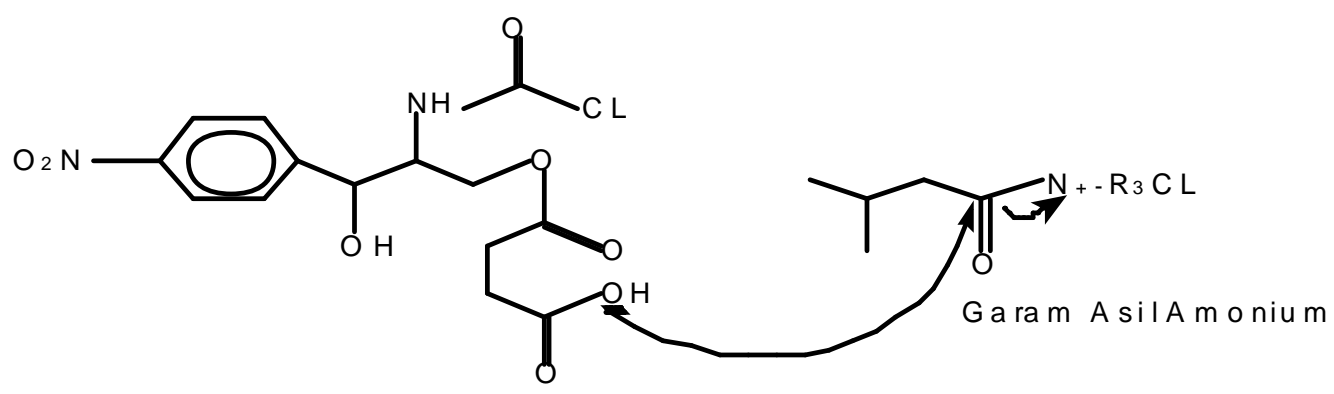

C A P -S uk sinat

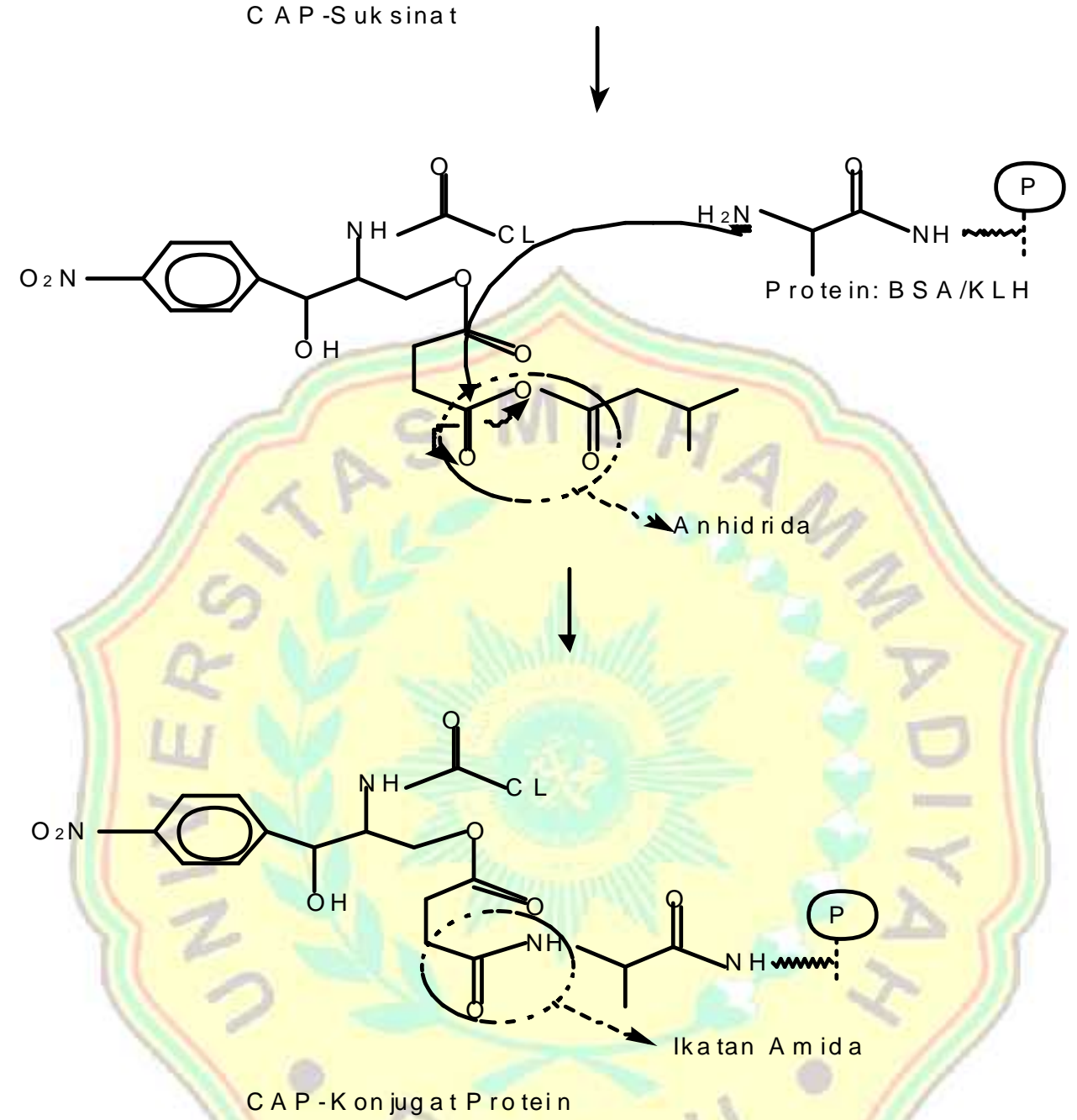

Gambar 3. Mekanisme Reaksi Sintesa Kloramfenikol Protein Konjugat

Pereaksi tributil amin merupakan suatu amina tersier. Pereaksi ini tidak dapat membentuk amida dengan klorida asam akan tetapi membentuk molekul antara reaktif yaitu "garam asil amonium" yang bersifat tidak stabil. Molekul ini tidak mengganggu pembentukan amida antara klorida asam dengan $\mathrm{NH}_{2}, \mathrm{RNH}_{2}, \mathrm{R}_{2} \mathrm{NH}$ atau molekul protein. Konjugasi hapten-protein pada metoda mixed anhidrad, ikatan peptida terjadi pada gugus amin terminal residu lysine atau pada gugus karboksil (asam glutamat dan asam aspartat pada sisi protein) juga pada terminal residu sistein yaitu grup sulfuhidril (-SH) bebas (Tijsen, 1990)

Hasil analisa metoda KCKT dari 10 ppm larutan immunogen (CAP-BSA dan CAP-KLH) diketahui bahwa kedua larutan immunogen tidak mengandung CAP bebas karena puncak CAP tidak terlihat pada menit 
ke 9,2. Tinggi puncak CAP standar pada konsentrasi $10 \mathrm{ppm}$ adalah $22 \mathrm{~mm}$ dengan waktu retensi 9,2 menit. Pada Lampiran 3 disajikan kromatogram KCKT larutan CAPBSA dan CAP-KLH. Analisa ini dilakukan untuk memastikan bahwa molekul CAP telah terpisah dari larutan imunogen setelah dilakukan pemurnian dengan cara Dialisa. Immunogen ini akan digunakan untuk penyuntikan kelinci dan analisa ELISA kompetitif.

Hasil uji kesesuaian sistem berdasarkan penyuntikan CAP standar sebanyak $20 \mu \mathrm{l}$ pada konsentrasi $10 \mathrm{ppm}$ yang dilakukan Senta (2003) diperoleh waktu retensi CAP selama 11,6 menit. KCKT merupakan salah satu metoda yang digunakan untuk memisahkan campuran senyawasenyawa kimia menjadi komponenkomponennya. Pada KCKT, fase gerak mengalir ke kolom dengan cara dipompa. Larutan contoh disuntikan melalui katup penyuntik akan terbawa oleh fase gerak dan masuk ke dalam kolom, dan dengan fase gerak akan berjalan melewati detektor. Detektor akan mendeteksi secara terpisah senyawa-senyawa yang ada alam contoh dan disajikan oleh rekorder berupa kurva dan puncaknya. Pemilihan pelarut pada KCKT dapat dilakukan berdasarkan sifat kepolaran dari contoh dan fase gerak yang dipakai (CCM, 2002).

Imunogen hasil sintesis disuntikan ke kelinci New Zealand White secara subkutan. Pengambilan darah untuk pengujian titer dan penentuan kandungan IgG dilakukan 10 hari setelah booster pada intravena teling sebanyak $50 \mathrm{ml}$. Darah yang diperoleh kemudian di sentrifus pada $3000 \mathrm{rpm}$ selama 15 menit sehingga diperoleh serum. Serum kemudian di dialisis dengan buffer phosfat dan dipurifikasi dengan kromatografi kolom protein A sepharose. Kondisi buffer sangat mempengaruhi kesuksesan purifikasi antibodi karena kondisi buffer dapat memperbaiki affinitas pengikatan kolom dan mempertahankan aktivitas pengikatan antibodi. Antibodi spesifik diperoleh dari hasil elusi kolom protein A sepharose dengan buffer sitrat dengan $\mathrm{pH}$ 4. $\mathrm{pH}$ fraksi antibodi yang diperoleh harus dijadikan netral untuk memaksimalkan integritas antibodi (Burgess, 1995). Antibodi yang telah dipurifikasi kemudian ditentukan konsentrasi antibodi secara spektrofotometri pada panjang gelombang $280 \mathrm{~nm}$.

Pada tabel 2 disajikan data konsentrasi IgG dari hasil purifikasi serum darah kelinci yang diukur dengan spektrofotometer pada panjang gelombang $280 \mathrm{~nm}$. Kandungan IgG dalam serum ditentukan untuk menghitung konsentrasi pelapisan antibodi pada lempeng mikro dan perhitungan konsentrasi penambahan antibodi pada saat pengujian ELISA. Metoda purifikasi bertujuan untuk memisahkan senyawa-senyawa lipid dan protein-protein lainnya sehingga preparasi IgG akan lebih murni $85 \%$.

Tabel 2. Data konsentrasi IgG dari hasil purifikasi serum darah kelinci

\begin{tabular}{|c|c|c|}
\hline \multirow{2}{*}{$\begin{array}{c}\text { Pengambilan } \\
\text { Darah }\end{array}$} & \multicolumn{2}{|c|}{ Kandungan IgG mg/ml } \\
\cline { 2 - 3 } & CAP - BSA & CAP - KLH \\
\hline 2 & 2,75 & 2,63 \\
\hline 3 & 2,65 & 2,82 \\
\hline 4 & 1,28 & 2,77 \\
\hline 5 & 1,56 & 2,82 \\
\hline 6 & 2,11 & 5.36 \\
\hline Rata-rata & 2,07 & 2,21 \\
\hline
\end{tabular}

Faktor yang menentukan dalam produksi antibodi diantaranya adalah sifat imunogen, adjuvan, pemilihan hewan, rute injeksi, dan dosis. Efekitivitas imunogen dapat ditingkatkan dengan adjuvan. Adjuvan dapat memodifikasi imunogen dengan menyebabkan perubahan struktural atau elektrostatik sehingga meningkatkan imunogenisitas. Adjuvan juga bekerja pada 
tingkat sel dari sistim imun inang dengan membentuk depot imunogen sehingga memperlambat pelepasannya dari lokasi inokulasi, menarik sel-sel mononuklear ke lokasi inokulasi, meningkatkan sirkulasi limfosit dan merangsang fagositosis oleh makrofag.

Dalam penelitian ini digunakan adjuvan freund yaitu terdiri atas campuran minyak mineral dan pengemulsi, baik dengan mikobakteria (adjuvan lengkap freund: FCA, Freund's Complete Adjuvan) ataupun tanpa mikobakteria (adjuvan tak lengkap freund : FIA, Freund's Incomplete adjuvant). FCA masih dianggap sebagai salah satu dari adjuvan paling kuat (Dalsgaard, 1987). FCA merangsang respon antibodi yang kuat untuk waktu yang lama dengan jalan memperlambat pelepasan emulsi. Beberapa peneliti menganjurkan bahwa jika dosis pertama diberikan dalam FCA, maka boster harus diberikan dalam FIA untuk menghindari reaksi hipersensitivitas yang hebat (Goding, 1986).

Menurut Lelliot dan Stead (1987), antibodi dapat diproduksi dengan baik pada kelinci. Hal ini didukung oleh pendapat Ball et all (1990) bahwa kelinci paling sering digunakan, karena hewan ini mudah diperlihara, mudah penanganannya dan juga tidak mahal. Selain itu Klement (1990) mengemukakan bahwa kelinci dapat menghasilkan antibodi dengan presipitasi yang sangat baik, sangat stabil dalam penyimpananya, fraksi immunoglobulin mudah dimurnikan, aviditas dan affinitas tinggi untuk menguji antigen spesifiknya.

Teknik injeksi imunogen ke dalam tubuh kelinci yang digunakan adalah secara subkutan. Teknik ini bertujuan untuk memperlambat pelepasan immunogen ke dalam aliran darah (Lelliot dan Stead 1987). Jalur secara subkutan adalah jalur yang paling sering digunakan oleh karena teknik ini lebih mudah, dapat dilakukan dengan volume yang lebih banyak per satu tempat injeksi. Kecepatan absorbsi tergantung pada aliran darah pada area injeksi, aktivitas otot dan kontak area (Bratawidjaja, 2002).

Antibodi yang diproduksi pada penelitian ini adalah antibodi poliklonal karena serum yang dikumpulkan dari hewan yang diimunisasi mengandung antibodi terhadap antigen yang dipakai untuk imunisasi tetapi juga antibodi terhadap antigen lingkungan lainnya yang mungkin telah masuk ke tubuh hewan. Antibodi ini mempunyai isotipe yang berbeda-beda dan afinitas berbeda-beda. Sifat antibodi poliklonal ini kurang spesifik akan tetapi dapat mempertahankan sensitivitasnya serta relatif stabil.

\section{KESIMPULAN}

Metoda konjugasi andhidrad dapat digunakan pada preparasi immunogen, dan jumlah kloramfenikol yang terkonjugasi ke asam amino bebas dari molekul protein untuk antigen CAP-BSA adalah 18,38 dan untuk CAP-KLH adalah 781,82. Antibodi poliklonal CAP-BSA dan CAP-KLH yang diproduksi dengan rata-rata kandungan IgG CAP-BSA 2,07 mg/ml dan IgG CAP-KLH $2,21 \mathrm{mg} / \mathrm{ml}$.

\section{SARAN}

Antigen dan Antibodi hasil sintesa dapat digunakan sebagai prangkat analisa pengembangan metoda ELISA kompetitif pada pemeriksaan residu kloramfenikol.

\section{DAFTAR PUSTAKA}

Bahri, S. Murdiati, T.B., Maryam, R dan Yuningsih. 1990. Senyawa Golongan Tetrasiklin pada Susu Sapi Rakyat di Beberapa Desa di Kabupaten 
Pasuruan, Jawa Timur. Laporan Intern Balitvet.

Beyzari, K., Hampton, S., Kwasowski,P., Fickling,S. 1987. Comparison of horsradish peroxidase and alkaline phosphatase-labelled antibodies in enzyme-immunoasay. $\mathrm{J}$. Immunoassay. 187-4.

Chu, F.S. 1990. Immunoassay; Principles and General considerations. Department of Food Microbiology and Toxicology University of Wisconsin, Madison.USA

Crowther, J.R. 1995. Methods in Molecular Biology. ELISA Theory and Practice. Humana Press .42:34-99.

Dalsgaard, K. $1987 . \quad$ Adjuvants. Immunolpath.17:145-152.

Dixon-Holland D,E and Deborah. 1992. ELISA and its Application for Residue Analysis of Antibiotics and Drugs in Products of Animal origin.

FAO. 1990. Residue of Some Veterinary Drugs in Animals and Foods. FAO, Food and Nutrition paper no 41/2. Monograph prepared by the $34^{\text {th }}$ meeting on the joint $\mathrm{FAO} / \mathrm{WHO}$ expert committee on food additives. Geneva.

Haagsma, N., Water der Water, C. 1992. Immunochemical Methods in the Analysis of Veterinary Drugs Residues.Plenum Press. 81-93.

Klement, Z.K., and Rudolph, D.C. 1990. Methods in Phytobacteriology. Academic Kiado. 518.

Komar, M., Marinsch, J., Marinsch, J., Somogk-Gaemol, K., Ivanic,S. and Milohnoja, M. 1990. Survey Of Sulphonamide Residues in Urine
Smaples, Animal Tissues and Food of Animal Origin in Solvenia In 1986, 1987 and 1988.In Residues of Veterinary Drugs in Food. Proceedings of Euro Residue Conferce, Noordwijkerhout. The Netherlands. 246-7.

Lelliot, R. A and Stead, D.E. 1987. Methods for Diagnosis of Bacterial Diseases of Plants. Plant Pathology . Melbourne. 216

Murdiati, T.B and Bahri, S. 1991. Pola Penggunaan Antibiotika dalam Peternakan Ayam di Jawa Barat, Kemukinan Hubungan dengan Masalah Residu. Proceedings Kongres ilmiah ke-8 ISFI, Jakarta. 445-8.

Seameo Biotrop, 2002. ELISA Workshop: Analysis of Aflatoxin B1 in Peanuts. Organised by University of Sydney. Bogor.

Salybury, C.D.C., Chan, W., Peterson, J.R., Macneil, J.D and Krenendonk, C.A. 1990. Case Report: An Investigation of Chlortetracycline and Oxytetracycline Residues in Suspect Swine Slaughtered in Manitoba, Canada. 1988. Food Additive and Contaminants. 7:363-373.

Schlatter, C. 1990. Toxicological Assesment of Xenobiotics in Foods of Animal Origin. In Residues of Veterinary Drugs in Food. Proceedings of the Euro Residue Conferece Noordwijkerhout, The Netherlands. 65-75.

Sudarwanto, M. 1990. Residu Antibiotika di dalam Air Susu Ditinjau dari Kesehatan Masyarakat Veteriner dalam Kumpulan Makalah Seminar Nasional. Penggunaan Antibiotika 
dalam Bidang Kedokteran Hewan. Jakarta.

Szurdoki, F., Bekheit, K.M., Marco, M.P., Goodrow, M.H and Hammock, D.
1995. Important Factor in Hapten Design and Enzyme Linked Immunosorbent Assay Development. In New Frontier in Agr chem Immunoasssays. 39-64.

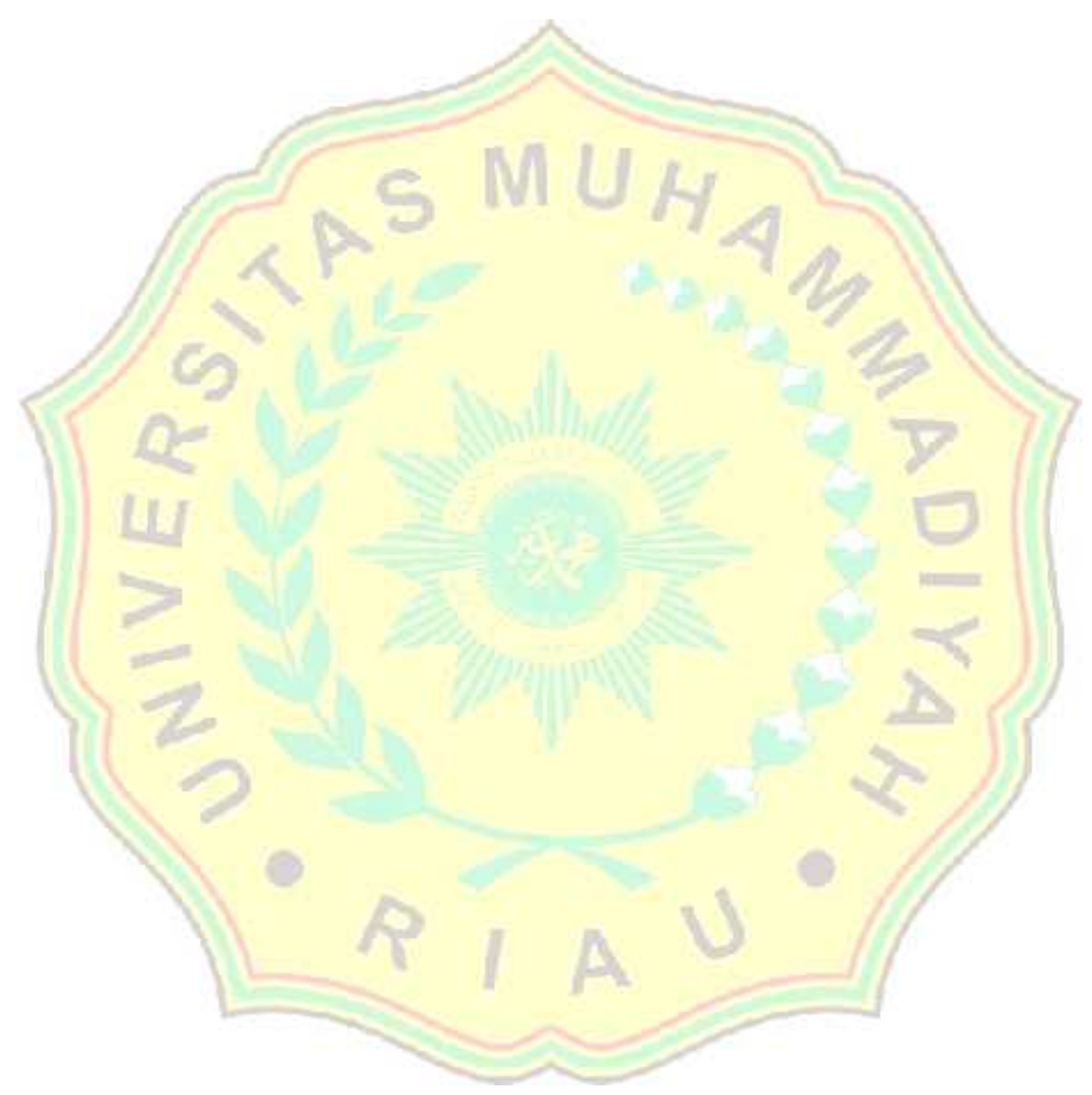

